\title{
PROTECTING THE AUDITOR'S WORK PRODUCT FROM THE IRS
}

Congress has given the Internal Revenue Service (IRS) broad investigatory powers to audit taxpayers, ${ }^{1}$ but these powers should not be unlimited. ${ }^{2}$ Many Certified Public Accountants (CPAs) seek some limitation on IRS access to the workpapers the CPA prepares during the annual audit of a company's financial statements. ${ }^{3}$ Specifically, CPAs resist IRS access to their analysis of a company's tax accounts ${ }^{4}$ and to their audit work programs. ${ }^{5}$

The IRS views the CPA's workpapers as valuable tools in

1. I.R.C. $\$ 7602$ (1976). "The power of the IRS to investigate the records and affairs of taxpayers has long been characterized as an inquisitorial power . . ." United States v. Matras, 487 F.2d 1271, 1274 (8th Cir. 1973). See note 9 infra and accompanying text. Such "inquisitorial" powers are a necessary part of our self-reporting system of taxation. See note 18 infra and accompanying text.

2. "[T]he Government may not exercise its investigative and inquisitorial power without limit . . . " United States v. Harrington, 388 F.2d 520, 523 (2d Cir. 1968). See United States v. Morton Salt Co., 338 U.S. 632, 653 (1950).

3. As part of this review of the financial statements, the CPA prepares audit workpapers. These workpapers consist of "the records kept by the independent auditor of the procedures he followed, the tests he performed, the information he obtained, and the conclusions he reached pertinent to his examination. Working papers, accordingly, may include work prograuns, analyses, meinoranda, letters of confirmation and representation, abstracts of company documents, and schedules or commentaries prepared or obtained by the auditor." 1 AICPA PROFEsSIONAL STANDARDS (CCH) AU \& 338.03. The courts generally permit IRS accoss to audit workpapers. See, e.g., United States v. Arthur Young \& Co., 82-1 U.S.T.C. I 9320 (2d Cir. 1982). But see notes 4-5 infra and accompanying text for the portions of the workpapers that CPAs want to deny the IRS. Professional accounting standards provide that "the objective of the ordinary examination of financial statements by the independent auditor is the expression of an opinion on the fairness with which they present financial position, results of operations, and changes in financial position in conformity with generally accepted accounting principles." $I d . \S 110.01$.

4. The review of the tax accounts shown in the tax accrual workpapers generally consists of three parts. The auditor prepares a summary of transactions recorded in the tax accounts of the company's general ledger, coinputes the tax provision (estimate of tax liability) for the year being audited; and then prepares the tax contingency memorandum, discussing items reflected in the financial statements about which he is uncertain as to the ultimate tax treatment by the IRS. I Internal Revenue Manual (CCH) $\$ 4024.2$ (May 14, 1981). See United States v. Arthur Andersen \& Co., 474 F. Supp. 322, 327 n.6 (D. Mass. 1979), appeal dismissed as moot, 623 F.2d 720 (1st Cir.), cert. denied, 449 U.S. 1021 (1980).

5. The audit work prograin is the "Inaster plan" for the audit. It details the audit procedures that are to be performed. As the work is performed the auditor cliecks off the steps completed. United States v. Coopers \& Lybrand, 550 F.2d 615, 617 (10th Cir. 1977); United States v. Arthur Andersen \& Co., 474 F. Supp. 322, 327 n.6 (D. Mass. 1979), appeal dismissed as moot, 623 F.2d 720 (1st Cir.), cert. denied, 449 U.S. 1021 (1980). 
reviewing company tax returns. ${ }^{6}$ Section 7602 of the Internal Revenue Code (Code) grants the IRS the power to reach such workpapers. The section permits the IRS to summon "any . . . person the Secretary or his delegate may deem proper . . . to produce such books, papers, records, or other data ... as may be relevant or material to" an inquiry into a taxpayer's tax hability. ${ }^{7}$ The courts have given this statute a liberal construction, ${ }^{8}$ describing the IRS's powers as "inquisitorial"9 and comparing them to the powers of a grand jury. ${ }^{10}$ Two courts have applied this hiberal construction to permit the IRS access to auditors' workpapers. ${ }^{11}$ The other two courts considering the issue have denied access based on the public benefits from unrestricted CPA audits. ${ }^{12}$ The CPA auditors believe that IRS access to their

6. See Nath, Internal Revenue Service Summonses for "Sensitive" Accountant's Papers, 34 VAND. L. REv. 561 (1981) (supporting full IRS access to CPAs' workpapers).

The IRS considers many third party documents to be useful tools in performing its audits. This comment focuses only on the CPA auditor's workpapers. For examples of cases involving other IRS tools, see Couch v. United States, 409 U.S. 322 (1973) (information used by a third party tax return preparer); Reisman v. Caplin, 375 U.S. 440 (1964) (workpapers prepared by an accountant working for an attorney); United States v. Noall, 587 F.2d 123 (2d Cir. 1978), cert. denied, 441 U.S. 923 (1979) (workpapers prepared by conpany's own imternal auditors); First Nat'l Bank of Mobile v. United States, 160 F.2d 532 (5th Cir. 1947) (records of company's bank); United States v. El Paso Co., 82-2 U.S.T.C. I 9534 (5th Cir. 1982) (tax contingency nieniorandum prepared by company's own tax department).

7. I.R.C. \& 7602(2) (1976).

8. See, e.g., United States v. Euge, 444 U.S. 707, 714-16 (1980); United States v. Continental Bank \& Trust Co., 503 F.2d 45, 50 (10th Cir. 1974).

9. See, e.g., United States v. Matras, 487 F.2d 1271, 1274 (8th Cir. 1973); Falsone v. United States, 205 F.2d 734, 737 (5th Cir. 1953), cert. denied, 346 U.S. 864 (1953).

10. See, e.g., United States v. Matras, 487 F.2d 1271, 1274 (8th Cir. 1973); Foster v. United States, 265 F.2d 183, 186-87 (2d Cir.), cert. denied, 360 U.S. 912 (1959); United States v. Acker, 325 F. Supp. 857, 862 (S.D.N.Y. 1971).

The IRS does not need to show probable cause to support its summons because such a requirement would unduly restrict its powcr to investigate. See, e.g., United States v. Powell, 379 U.S. 48, 53 (1964); United States v. Morton Salt Co., 338 U.S. 632, 642-43 (1950); United States v. Shlon, 420 F.2d 263, 266 (2d Cir. 1969), cert. denied, 397 U.S. 1074 (1970); De Masters v. Arend, 313 F. 2d 79, 88 (9th Cir.), appeal dismissed, 375 U.S. 936 (1963).

11. Two federal district courts have upheld IRS summonses of tax accrual workpapers and audit work programs. See United States v. Price Waterhouse \& Co., 515 F. Supp. 996 (N.D. Ill. 1981); United States v. Arthur Anderseu \& Co., 474 F. Supp. 322, 329 (D. Mass. 1979), appeal dismissed as moot, 623 F.2d 720 (1st Cir.) (Arthur Andersen \& Co. had turncd the workpapers over to the IRS), cert. denied, 449 U.S. 1021 (1980). The Fifth Circuit has recently supported access to tax contingency memoranda in United States v. El Paso Co., 82-2 U.S.T.C. ๆ 9534 (5th Cir. 1982). The case concerned tax workpapers prepared by the company's own tax departinent. Certainly the company's own documeuts should not be denied to the IRS; thus, El Paso adds hittle to the analysis of independeut CPAs' workpapers.

12. The two courts of appeals considering the issue have denied access to some of the auditor's work papers. In the first of the CPA auditor workpaper cases, the Court of Appeals for the Tenth Circuit denied access to the auditor's workpapers. United States v. Coopers \& Lybrand, 550 F.2d 615 (10th Cir. 1977). The Court of Appeals for the Second Circuit originally rejected the Coopers \& Lybrand reasoning in a case that dealt specifically with internal audit workpapers. See 
workpapers threatens their ability to perform an effective audit of company financial statements. ${ }^{13}$ CPA audits are an important protection for the investing public against misleading information in corporate financial statements. Thus the Securities and Exchange Commission, as well as the accounting profession and the corporate tax community, believe that the IRS's access to auditors' workpapers should be restricted. ${ }^{14}$

This comment addresses the conflict between the IRS and the CPAs. Part I discusses the IRS's reasons for wanting access to the auditors' workpapers and the CPAs' reasons for strongly opposing such access. ${ }^{15}$ Part II explores possible responses to this problem and reviews the approach of the IRS, suggestions by the CPAs, and possible court responses. It then suggests a possible solution requiring congressional action. ${ }^{16}$ The comment concludes that the appropriate congressional response would be to adopt as positive law a solution similar to that used by the Court of Appeals for the Second Circuit in United $v$. Arthur Young \& Co., which is one of the cases that granted protection to the auditors. ${ }^{17}$

\section{The Dispute}

A. The Position of the IRS.

The IRS's broad investigatory power is a necessary part of our

United States v. Noall, 587 F.2d 123, 126-27 (2d Cir. 1978), cert. denied, 441 U.S. 923 (1979). Later, when directly faced with the issue, the Court of Appeals for the Second Circuit limited access to the auditor's workpapers. See United States v. Arthur Young \& Co., 82-1 U.S.T.C. 9320 (2d Cir. 1982). This decision partially reversed the district court's decision to pernit access to the auditor's workpapers while denying access to the audit work programs. See United States v. Arthur Young \& Co., 496 F.Supp. 1152 (S.D.N.Y. 1980); Caplin, Should the Service be Permitted 10 Reach Accountant's Workpapers? 51 J. TAX'N 194 (1979); Sumner \& Reed, New IRS Guidelines are Accountants' Best Hope for Protecting Tax Accrual Workpapers, 27 TAX'N FOR AccT. 72, 73-75 (Aug. 1981); Note, A Balancing Approach to the Discoverability of Accountants' Tax Liability Workpapers Under Section 7602 of the Internal Revenue Code, 60 WASH. U.L.Q. 185, 200-08 (1982).

13. See Hanson \& Brown, CPAs' Workpapers: The IRS Zeros In, J. ACcr. 68, 70 (July 1981); Professional, J. Accr. 18, 20 (Mar. 1981) (statement by D. R. Carmichael, vice-presidentauditing, American Institute of Certified Public Accountants (AICPA)). See generally United States v. Coopers \& Lybrand, 413 F. Supp. 942, 953-54 (D. Colo. 1975), affd, 550 F.2d 615 (10th Cir. 1977) (testimony of Marvin Stone, past president of A1CPA). See also Remarks by Roscoe L. Egger, Jr., Commissioner of Internal Revenue, note 73 infro and accompanying text.

14. Hanson \& Brown, supra note 13 , at 68.

15. See notes 18-71 infra and accompanying text.

16. See notes $143-62$ infra and accompanying text.

17. See note 12 supra. This comment advocates an approach very similar to that taken by both the Arthur Young court and by Note, supra note 12 at 200-08. This comment attempts to examine alternative solutions to the CPA-IRS dispute and provide arguments in support of the Arthur Young court's result. 
self-reporting systein of taxation. ${ }^{18}$ The IRS is at a disadvantage in its examination of tax returns because the taxpayer or his agent possesses the sources of information the IRS needs to audit the return. Neither the taxpayer nor his agents should be permitted to refuse IRS access to the materials used to prepare the taxpayer's tax return; the IRS cannot conduct an audit without this information. Similarly, the taxpayer cannot be permitted to offer the IRS volumes of records through which the IRS cannot possibly sift. ${ }^{19}$ The IRS agent should be given the taxpayer's records in their most useful form. Ideally, the IRS should have a "road map" that explains the tax return and highlights the taxpayer's positions on questionable iteins.

The IRS views the CPA's audit workpapers as such a road map, ${ }^{20}$ and the audit work prograns provide the key to understanding the audit workpapers. ${ }^{21}$ Also, the work programs list the areas in which the CPA has done substantial work, and thus show the IRS agent those areas that may require less attention. ${ }^{22}$ More importantly, the tax accrual workpapers-especially the tax contingency memorandum contained in the workpapers-reveal the CPA's assessinent of the company's potentially questionable tax positions. ${ }^{23}$ The tax contingency memorandum effectively provides the IRS with an outline for its investigation. The meinorandum is also useful to the IRS because the CPA auditor is often privy to tax positions assumed by the coinpany that the company would prefer the IRS not know. ${ }^{24}$ This does not mean that the company is breaking the law-the CPA would indirectly disclose this ${ }^{25}$ - but it does mean that there are gray areas in the tax code that the taxpayer can legally use to his advantage, but would

18. United States v. Bisceglia, 420 U.S. 141, $145-46$ (1975); United States v. Coopers \& Lybrand, 413 F. Supp. 942, 954 (D. Colo. 1975), aff d, 550 F.2d 615 (10th Cir. 1977). See Raymond, New Case Sets Limits on Service's Summons Power Under Section 7602, 44 J. TAX'N 172 (1976).

19. Hanson \& Brown, supra note 13 , at 70 . Jerome Kuntz, former Commissioner of Internal Revenue, commented that the taxpayer cannot be permitted to say: "Here is the haystack; the needle is in here, somewhere, and it's your problem to find it." Id.

20. United States v. Coopers \& Lybrand, 550 F.2d 615, 621 (10th Cir. 1977). See generally Ord, The IRS's Right of Access to the CPA's Workpapers and Client Records, 4 TAX ADVISER 516 1973). See also United States v. Matras, 487 F.2d 1271, 1275 (8th Cir. 1973).

21. See United States v. Coopers \& Lybrand, 550 F.2d 615, 621 (10th Cir. 1977).

22. See United States v. Coopers \& Lybrand, 413 F.Supp. 942, 947 (D. Colo. 1975), affd, 550 F.2d 615 (10th Cir. 1977); Barnes, IRS Access to Accountants' Workpapers: the Coopers \& Lybrand Case, 7 TAX ADVISER 44, 45 (1976).

23. See note 4 supra.

24. Umited States v. Arthur Young \& Co., 82-1 U.S.T.C. $\$ 9320$ (2d Cir. 1981); United States v. Coopers \& Lybrand, 413 F. Supp. 942, $953-54$ (D. Colo. 1975), affd, 550 F.2d 615 (10th Cir. 1977). The tax contingency memorandun discusses these tax positions. See note 4 supra.

25. See text accompanying notes $108-18$ infra. 
rather not go to court to defend. For example, a corporation usually may deduct its president's salary as a business expense, but if the president is a major stockholder of the company, part of the salary is arguably a nondeductible dividend. ${ }^{26}$ Also, fixed assets may be depreciated over their expected lives, and this depreciation is a deductible expense. ${ }^{27}$ Reasonable persons may differ, however, on the expected life of the asset. A company will discuss such gray areas with its auditors, but it cannot be expected to discuss thein as candidly with an investigating IRS agent. Thus the CPA's workpapers are highly useful to the IRS. ${ }^{28}$

\section{B. The Position of the CPAs.}

The goal of the CPA's audit is to prepare an opinion on the compliance of a company's financial statements with Generally Accepted Accounting Principles (GAAP). ${ }^{29}$ GAAP, in the forin of Financial Accounting Standards Board (FASB) 5, require auditors to review contingencies that could affect the company's financial statements. ${ }^{30}$ One such contingency is that the IRS will audit the company's tax return and make material adjustments to it. The auditor must estimate the probabilities of such adjustments and their magnitude. ${ }^{31}$ The accountant's principle of conservatism ${ }^{32}$ requires him to analyze the return to determine the result "if every assumption on which the taxpayer based his tax were to go against him in solne kind of litigation." 33 The ac-

26. See United States v. Coopers \& Lybrand, 413 F. Supp. 942, $953-54$ (D. Colo. 1975), aff d, 550 F.2d 615 (10th Cir. 1977).

27. I.R.C. $\$ 167$. Recent revisions to the tax code will make this problent less pronounced in the future. See Economic Recovery Tax Act of 1981, Pub. L. No. 97-34, \$§ 201-09, 95 Stat. 172, 203-07 (codified in scattered sections of 26 U.S.C.); United States v. El Paso Co., 82-2 U.S.T.C. II 9534 (5th Cir. 1982).

28. See Nath, note 6 supra, at 1573-1614. Nath also points out that the audit workpapers may help show the fraudulent intent needed as proof in a tax fraud investigation. Id. at 1581-83. His analysis ignores the CPA's duty to indirectly "blow the whistle" on illegalities. See notes 10818 infra and accompanying text.

29. See note 3 supra.

30. 4 AICPA Professlonal Standards (CCH) AC $\$ 4311$ (incorporates FasB 5, as amended).

31. Id. $\S 4311.08$.

32. Conservatisn is the hallmark of accountants, and accounting literature supports the convention of conservatisn. "Frequently, assets and liabilities are measured in a coutext of significant uncertainties. Historically, nanagers, investors, and accountants have generally preferred that possible errors in measurenient be in the direction of understatement rather than overstatement of net income and net assets. This has led to the convention of conservatism." Id. at AU $\S 4311.83$.

33. United States v. Coopers \& Lybrand, 413 F. Supp. 942,953 (D. Colo. 1975), affd, 550 F.2d 615 (10th Cir. 1977) (testimony of Marvin Stone, past president of the American Institute of Certified Public Accountants). 
countant then sets forth an analysis of tax contingencies, which includes the "worst case," in the tax contingency memorandum in the tax accrual workpapers.

The auditor needs the company's assistance in preparing this memorandum. An audit requires candid discussions between the auditor and company personnel; general ledgers and journal entries simply do not reveal fully a company's financial position. ${ }^{34}$ CPAs fear that permitting IRS access to the auditors' workpapers will cause knowledgable companies to be less candid with their auditors. Because they fear that this potential loss of candor will impair the quality of their audits, CPAs oppose IRS access to their workpapers. ${ }^{35}$ Since the IRS began aggressively pursuing audit workpapers, CPAs have noticed that coinpanies have become reluctant to discuss sensitive issues with them. ${ }^{36}$ Without candid discussions, the auditor cannot review contingencies as required by FASB 5 . As a result, the auditor may not be able to give an unqualified opimion on the company's financial statements; instead, he may have to give a qualified or adverse opimion or a disclaimer. ${ }^{37}$ The Securities and Exchange Commission and other users of financial statements object to these limited auditors' opinions. ${ }^{38}$ Arguably, their disapproval of these opinions could force companies to be fully candid

34. In performing an audit, auditors do more than review the company's books. The third Standard of Field Work of Generally Accepted Auditing Standards states that "[s]ufficient competent evidential matter is to be obtained through inspection, observation, inquiries, and confirmations." 1 AlCPA Professional STANDARDS (CCH) AU \$ 150.02.

35. See United States v. Arthur Young \& Co., 82-1 U.S.T.C. I 9320 (2d Cir. 1982); United States v. Price Waterhouse \& Co., 515 F.Supp. 996, 1000 n.6 (N.D. Ill. 1981); United States v. Coopers \& Lybrand, 413 F. Supp. 942, 953 (D. Colo. 1975), affd, 550 F.2d 615 (10th Cir. 1977); Hanson \& Brown, note 12 supra.

36. News Report, J. Acct. 8 (May 1981); Professional, J. Acct. 19 (Mar. 1981) (statement by William L. Raby, chairman of the AICPA Federal Taxation Executive Committee).

37. Auditors are required "to obtain sufficient competent evidential matter . . . to afford a reasonable basis for an opinion on the financial statements." Without this information, the auditor cannot "issue an unqualified opinion on the financial statements." Auditing Interpretation of SAS No. 31: Evidential Matter, J. ACcT. 122 (Mar. 1981). One such limitation affecting the opmion would be on "the auditor's access to information he considers necessary to audit the tax accrual." Id. Auditors use four different standard opimions to report the results of their audits. The unqualified opinion "states that the financial statements present fairly financial position, results of operations and changes im financial position in conformity with generally accepted accounting principles [which mandate adequate disclosure] consistently apphed." 1 AICPA ProfessionAL STANDARDS (CCH) AU $\S 509.28$. A qualified opinion states that the auditor found comphance "except for" or "subject to" a inaterial departure from "generally accepted accounting principles, a material change in accountimg primciples apphed, or a significant uncertainty." Id. § 509.29. "An adverse opinion states that financial statements do not present fairly the financial position, results of operations or changes in financial position in conformity with generally acceptcd accounting principles." Id. $\S 509.41$. Fmally, a "disclaimer of opinion states that the auditor does not express an opinion on the financial statements." Id. \$ 509.45.

38. Barnes, supra note 22 , at 46. 
with their auditors despite the risk of an IRS review of the auditors' workpapers. ${ }^{39}$ As a practical matter, however, companies probably will reveal only the minimum amount of information necessary to satisfy their auditors. Obviously the CPA cannot know that he is missing information unless he knows that the information exists, and the company is often the only source of some information. Auditors are the public's agents in reviewing financial statements. When fear of IRS summonses limits the auditors' reviews, the imvesting public will suffer because it cannot obtain critical information concerning coinpanies' financial positions.

Aside from the potential threat to the effectiveness of the auditing process, CPAs object to IRS review of their workpapers because they regard this review as a fishing expedition ${ }^{40}$ and as a mind-scan. ${ }^{41}$ Even though the IRS does not liave to show probable cause for its summonses, ${ }^{42}$ the courts usually will not let the IRS go on a true "fishing expedition," especially for docuinents held by parties other than the taxpayer. ${ }^{43}$ Thus, the courts protect the CPAs froin IRS "fishing expeditions" in their workpapers. ${ }^{44}$ Most courts do not protcct CPAs froin IRS mind-scans, however. The auditor's workpapers reveal his assessinent of the taxpayer's tax positions. Thus, access to such workpapers allows the IRS to scan the auditor's mind.

In Hickman v. Taylor ${ }^{45}$ the Supreme Court rejected a similar mind-scan of attorneys. In that case, the petitioner requested access to workpapers prepared by the respondent's attorney. These papers included mental impressions of the attorney. Despite a general policy toward liberal discovery, ${ }^{46}$ the Court limited access to the attorney's work product, thus guarding against a mind-scan of the attorney:

39. See United States v. Arthur Young \& Co. 82-1 U.S.T.C. I 9320 at 83829 (2d Cir. 1982) (Newman, J., concurring in part and dissenting in part); Nath, supra note 6, at 1291-93. See generally Bynum, Evidence-Privileged Communications-Accountant and Client, 46 N.C.L. REv. 419, 425 (1968).

40. United States v. Coopers \& Lybrand, 550 F.2d 615, 621 (10th Cir. 1977).

41. Diss \& Hanson, Tax Contingency Audit Workpapers: Current Developments, Observations, and Proposals, 12 TAX Adviser 104, 109 (1981). See United States v. Coopers \& Lybrand, 413 F. Supp. 942, $953-54$ (D. Colo. 1975), affd, 550 F.2d 615 (10th Cir. 1977); Hanson \& Brown, supra note 13, at 70 (July 1981).

42. See note 10 supra.

43. United States v. Coopers \& Lybrand, 550 F.2d 615, 621 (10th Cir. 1977); United States v. Theodore, 479 F.2d 749, 754 (4th Cir. 1973); First Nat'l Bank of Mobile v. United States, 160 F.2d 532, 536 (5th Cir. 1947); see United States v. Bisceglia, 420 U.S. 141, 146-47 (1975). Contra, United States v. Giordano, 419 F.2d 564, 568 (8th Cir. 1969), cert. denied, 397 U.S. 1037 (1970).

44. See United States v. Bisceglia, 420 U.S. 141, 146 (1975); Reisman v. Caplin, 375 U.S. 440, 445 (1964); see also I.R.C. § 7402(b) (1976).

45. 329 U.S. 495 (1947).

46. Id. at 506 . 
When Rule 26 and the other discovery rules were adopted, this Court and the members of the bar in general certainly did not believe or contemplate that all the files and mental process of lawyers were thereby opened to the free scrutinizing of their adversaries. And we refuse to interpret the rules at this time so as to reach so harsh and unwarranted a result. ${ }^{47}$

CPAs would argue that similarly "harsh and unwarranted results"48 occur when a court permits a mind-scan of a CPA. ${ }^{49}$

A mind-scan is an unwarranted result because it destroys the mental privacy that a professional needs to work effectively. The untenable nature of working without privacy led the Supreme Court to adopt the attorney work-product rule. In Hickman v. Taylor, the Court stated:

In performing his various duties, however, it is essential that a lawyer work with a certain degree of privacy, free from unnecessary intrusion by opposing parties and their counsel. . . This work is reflected ... [in] the "work product of the lawyer." Were such materials open to opposing counsel on mere demand, much of what is now put down in writing would renain unwritten. An attorney's thought, heretofore inviolate, would not be his own. . . . The effect on the legal profession would be demoralizing. ${ }^{50}$

Working without privacy is as demoralizing to the accounting profession as it would be to the legal profession. The CPAs have carried the mind-scan argument further, arguing that the IRS's use of the auditor's workpapers turns the auditor into an unpaid informer for the government. ${ }^{51}$ At least two courts have rejected similar conscriptions of private citizens into governmental service. In United States $v$. Humble Oil $\&$ Refining Co. 52 the Court of Appeals for the Fifth Circuit refused IRS access to company business records that the IRS wanted for an IRS research project. The court denied the IRS "an unrestricted license to enlist the aid of citizens in its data gathering projects."53 This case concerned gathermg data as opposed to direct IRS enforceinent, so the

47. Id. at 514.

48. Id.

49. It is interesting to note that the courts generally have not permitted a mind-scan of the IRS. Bames, supra note 22, at 46. See generally Rosenbloom, More IRS Information May Become Public due to Amended Freedom of Information Act, $45 \mathrm{~J}$. TAX'N 258, 261 (1976). This reluctance to permit access to IRS documents is changing, however. See Tax Analyst v. IRS, 50 U.S.L.W. 2338 (D.C. Cir. Mar. 1981).

50. 329 U.S. 495, 510-11 (1947); see Note, supra note 12 at 206 ("the analogy [between Hickman and the workpapers is strong.").

51. Hanson \& Brown, supra note 13, at 71.

52. 488 F.2d 953 (5th Cir. 1974), vacated, 421 U.S. 943 (1975) (to be considered in view of United States v. Biscegha, 420 U.S. 141 (1975)), affd on rehearing, 518 F.2d 747 (1975).

53. 488 F.2d at 963. 
Court may have felt less compelled to aid the IRS. Still, the case shows some desire to limit the IRS.

In $S E C$ v. Arthur Young \& Co. ${ }^{54}$ the Court of Appeals for the Nimth Circuit refused to turn CPA auditors into "an enforcement arm of the SEC." ss The SEC in that case wanted the auditors to adopt audit standards that would be more helpful to the SEC but that exceeded generally accepted auditing standards. Though the court recognized the advantages to the SEC of conscripting CPAs, the court noted that "the difficulty with [allowing such conscription] is that Congress has not enacted the conscription bill that the SEC seeks to have us fashion." 56 Due to the nature of our self-reporting system, the IRS arguably has some power to conscript necessary parties into service, ${ }^{57}$ but Congress has not given the IRS complete conscription powers. ${ }^{58}$

Despite the limits of the conscription argument, using an auditor the company hires and pays in a tax action against the conpany seenis unfair. The Supreme Court in Upjohn Co. v. United States implicitly considered fairness in reviewing IRS summonses. ${ }^{59}$ The case involved IRS access to information prepared by corporate employees necessary to secure legal advice from the corporation's lawyers. Though these employees were not members of the corporation's control group, the Court held that the attorney work-product rule protected their work from IRS review. Reiterating the concurrence of Hickman v. Taylor, 60 the origmal attorney work-product case, the Court remarked: " $D$ 'scovery was hardly intended to enable a learned profession to perform its functions . . . on wits borrowed from the adversary." "61 Admittedly, the CPA should not be an adversary of the IRS, but the CPA is hired by the taxpayer who is the party opposing the IRS in a tax investigation. Therefore, by using the CPA's work product, the IRS takes unfair advantage of the adversary's wits.

The preceeding argument stresses fairness; other CPA arguments against IRS access to workpapers focus on business practicalities.

54. 590 F.2d 785 (9th Cir. 1979).

55. $I d$. at 788 .

56. Id. See Hanson \& Brown, supra note 13, at 71. Again the policy reasons for aiding the IRS may be greater than those for aiding the SEC.

57. See Nath, supra note 6, at 1603-10.

58. Congress could require taxpayers to flag questionable items, as suggested by former IRS Commissioner Kuntz. See Discussion on "Questionable Positions, 32 TAX Law. 13, 15-16 (1978). Congress has not done so and permitting IRS access to the audit workpapers is a "backdoor" method of implementing Kurtz's proposal. United States v. Arthur Young \& Co., 82-1 U.S.T.C. If 9320 (2d Cir. 1982).

59. See 449 U.S. 383, 396 (1981); Hanson \& Brown, supra note 13, at 71.

60. 329 U.S. 495 (1947).

61. 449 U.S. at 396 (quoting Hickman v. Taylor, 329 U.S. 495, 516 (1947)). 
Courts have considered such practicalities in determining the propriety of IRS summonses by refusing to uphold IRS summonses that are overbroad. ${ }^{62}$ Also, IRS policy requires that "the burden of compliance with the [IRS] summons must not be unreasonably onerous." 63

CPAs assert that IRS access to their workpapers is detrimental to the audit and is expensive for the auditor. Auditors cannot review every transaction performed by a company during the year being audited; instead, they must perforn comphance tests to examme the company's ability to reflect its transactions fairly in its financial statements. Certainly an audit is worth little if the company knows in advance which transactions will be tested. Thus, work programs must be kept secret from the company being audited. ${ }^{64}$ Unfortunately, turning work programs over to the IRS means that compamies may eventually gain access to these work programs. ${ }^{65}$ If the company does gaim such access, the auditor must revise the audit work programs rather than follow common practice and reuse the programs. Even with revision, which is expensive, the auditor may not be able to create new programs sufficiently different from the old programs to preserve the integrity of the audit. ${ }^{66}$

Despite the practical appeal of these arguments, they do have latent weaknesses. Audit work programs are less secretive than the CPAs assert. Programs are reused, and after one audit a company becomes familiar with the common steps used in an audit. Similarly, many imdividuals move from accounting firms into corporate accounting departments. ${ }^{67}$ These forner firm employees often know the specific programs involved in an audit, or at least can readily guess the contents of audit work programs because they know generally accepted auditing practices. Thus, denying access based on a need for absolute secrecy of audit work programs serves only a limited purpose. Also, any IRS audit creates expense for someone. Hence, using expense as a criterion for assessing the enforceability of IRS summonses could unduly limit the IRS's ability to audit tax returns. One court has remarked that

62. See United States v. Theodore, 479 F.2d 749, 754 (4th Cir. 1973); United States v. Harrington, 388 F.2d 520, 523 (2d Cir. 1968); First Nat'1 Bank of Mobile v. United States, 160 F.2d 532 (5th Cir. 1947).

63. I INTERNAL REVENUE MANUAL, supra note $4, \S 4024.4$.

64. United States v. Coopers \& Lybrand, 413 F. Supp. 942, 948-49 (D. Colo. 1975), affd, 550 F. 2d 615 (10th Cir. 1977).

65. The IRS, as a matter of law, may be required to turn over to the taxpayer in later litigation any papers gained from the CPA auditor. 413 F.Supp. at 948 . But see Nath, supra note 6, at $1595-99$.

66. 413 F. Supp. at 948.

67. This is common knowledge among the "Big Eight" accounting firms. 
CPAs should consider the expense of IRS audits as an ordinary cost of doing business. ${ }^{68}$

Another argument against access to audit workpapers stresses the CPA's ethical obligation not to disclose confidential information obtained durimg an audit. ${ }^{69}$ This ethical argument has practical implications: companies will not give private information to their auditors unless the auditors respect their privacy. This ethical prohibition has limits, however. Sometimes the CPA unust disclose confidential information, ${ }^{70}$ for example, when he defends a suit charging neghigence in conducting an audit. Despite these limits, the CPA's loyalty inust be to his chent. Though the CPA is the pubhic's agent, he is still hired by the company under audit. ${ }^{71}$

\section{Possible Responses to the Problem}

\section{A. IRS Self-Control as a Solution.}

After several years of conflict over IRS access to auditors' workpapers, ${ }^{72}$ the IRS partially accepted the CPAs' position because the issue "had reached rather einotional proportions" and "had real potential for serious negative effects on the quahty of financial report-

68. United States v. Arthur Andersen \& Co., 474 F. Supp. 322, 331 (D. Mass. 1979), appeal dismissed as moot, 623 F.2d 720 (1st Cir.), cert. denied, 449 U.S. 1021 (1980).

69. 2 AICPA PRofessional Standards (CCH) ET § 301.01 .

70. Id.

71. Fortunately, the CPA is no longer forced into the position of choosing between disobeying his client's instructions to ignore an IRS summons and facing potentially severe penalties for not complying with the IRS's request. See Ord, note 20 supra, at 518-20. Current statutes permit a company whose auditor receives a summons to intervene when the court considers the enforceability of the summons. See I.R.C. $\$ 7609$. The company can then raise its own defenses against IRS access to the CPA's workpapers.

Companies inay raise, for example, defenses based on the fourth or fifth amendinents. Given the broad investigatory powers of the IRS, fourth amendment challenges tend to be unsuccessful, though the courts will narrow the suminons as appropriate. See United States v. Theodore, 479 F.2d 749, 754 (4th Cir. 1973); see also United States v. Arthur Young \& Co., 82-1 U.S.T.C. | 9320 (2d Cir. 1982); Couch v. United States, 409 U.S. 322, 335-36 (1973); United States v. Morton Salt Co., 338 U.S. 632, 651-54 (1950); Martim, Fourth Amendment Rights in an IRS Investigation, $48 \mathrm{~J}$. KAN. B.A. 333 (1979). But see GM Leasing Corp. v. United States, 429 U.S. 338 (1977).

Fifth anendment protection generally is not available to an intervenor in a third party summons case because the defense adheres to the person rather than to the information. See States, 409 U.S. 322 (1973); Fisher v. United States, 425 U.S. 391 (1976); Couch v. United States, 409 U.S. 322 (1973); Kenderline, The Internal Revenue Service Summons to Produce Documents: Powers, Procedures and Taxpayer Defenses, 64 MinN. L. Rev. 73, 90-93 (1979); Note No Fifth Amendment Privilege for Accountant-Prepared Tax Records in Attorney's Possession, 31 ARK. L. REv. 152 (1977).

72. For a history of this conflict, see Internal Revenue News Release IR-81-49, [1981] 10 Stand. Fed. TAX Rep. I 6598 (reinarks by Roscoe L. Egger, Jr., Commissioner of Internal Revenue). 


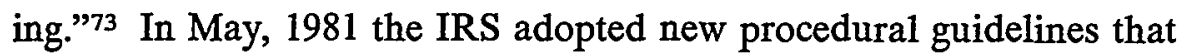
require the IRS agent to take the following steps before summoning auditors' workpapers:

1. The IRS agent must reconcile schedule M-1 of form $1120 ; 74$

2. The IRS must substantially complete the audit;

3. The agent must identify specific issues for investigation;

4. The agent must first request the needed information from the taxpayer;

5. The agent must limit the summons to the issues specifically identified; and

6. The Chief of the Exammation Division must approve the summons. ${ }^{75}$

These rules resolve some of the CPAs' objections to IRS access to their workpapers. The rules eliminate fishing expeditions by requiring the agent to identify specific issues in the summons. This limitation should also reduce the auditors' cost of complying with IRS summonses by reducing the number of summonses.

Because these rules do not resolve all of the CPAs' objections to IRS access, ${ }^{76}$ the CPAs have responded to the rule changes with guarded optimism. ${ }^{77}$ Since IRS access to workpapers is still possible, companies may believe they should limit communications with their auditors. Presumably, when issumg summonses, the IRS will specifically identify the sensitive issues that the client is reluctant to discuss. The company will remain reluctant to discuss these issues with the CPA so long as the IRS can reach the CPAs' workpapers. Thus, the rule changes do little to proinote candor between a taxpayer and its auditor. ${ }^{78}$ Also, the rule changes do nothing to relieve the unfairness of using the company's own auditor against it in a tax investigation. ${ }^{79}$

Apart from these considerations, the new rules are inadequate primarily because they require the IRS to police itself. The IRS inay still determine when to issue a summons, and presumably it will favor its interests over those of others. Once the IRS lias decided to summon workpapers, the courts inay allow the IRS to gain access to them. ${ }^{80}$ Certainly, given the split in the courts over IRS access, no one will

73. Id.

74. The 1120 is the corporate tax return. The Schedule $M-1$ is the form on which the agent reconciles book income and taxable income.

75. I INTERnal Revenue MANUAL, supra note $4, \S 4024.4$. (rules are paraphrased).

76. See notes 29-71 supra and accompanying text.

77. See Hanson \& Brown, supra note 13; Sumner \& Reed, supra note 12.

78. See text accompanying notes 34-37 supra.

79. See text accompanying notes 51-61 supra.

80. See note 12 supra. 
depend fully on the courts for protection. ${ }^{81}$ Also, the courts have considered IRS guidelines, which require the agency to comply with internal IRS procedures before requesting workpapers, to be merely nonbinding, informal rules. ${ }^{82}$ The IRS appears free to interpret the reach of its guidelines without ineaningful review by the courts; therefore, the present rules leave much control over access to workpapers with the IRS. Resolution of the problem requires inore protection for the workpapers.

\section{B. Proposals by the CPAs.}

CPAs have proposed that they limit the audit work they perforn by revising the requirements of FASB 5 . concerning the contingency review of tax accounts. ${ }^{83}$ For example, the portions of GAAP that require contingency review of the tax accounts could be abandoned. This self-protecting solution, however, would be harmful to both the public and the CPA profession. It would result in a less coinplete audit and the ultimate losers would be the investing public.

Another proposed solution is to change documentation procedures to ensure that the IRS could gain little from reviewing CPA audit workpapers. ${ }^{84}$ These workpapers guide the auditor in his work and provide support for his audit opinion. ${ }^{85}$ Also, they are the basis for review of the audit work by supervisors. ${ }^{86}$ These functions help to maintain the quality of the audit. If the auditor disguises his audit documentation, the workpapers will not fully serve their purposes. In ad-

81. See text accompanying notes 11-12 infra.

82. See Umited States v. Price Waterhouse \& Co., 515 F. Supp. 996, 999 (N.D. Ill. 1981); United States v. Arthur Andersen \& Co., 474 F. Supp. 322, 331 (D. Mass. 1979), appeal dismissed as moot, 623 F.2d 720 (1st Cir.), cert. denied, 449 U.S. 1021 (1980); see also United States v. Caceres, 440 U.S. 741 (1979).

83. Diss \& Hanson, supra note 41 , at 114.

84. Hanson \& Brown, supra note 13 , at 74-75. Work programs list the audit steps to be performed. The auditor completes eacli step and records on the audit program the location of the workpaper schedule that shows the documentation of the completed work. The schedule in the workpapers gives the details of the audit work performed and the results of the work. In the sehedule the auditor lists contingencies found in the tax analysis and then discusses the potential impact of these contingencies on the financial statements. The proposed alternative requires only a yes or no answer on the work program. Specifically, the audit work program would say: "Will any tax contingencies materially impact the financial statements?" The auditor generally would answer "no." This change would result in the IRS learning little from the audit workpapers. Beyond these simple answers, the CPA would prepare no record of the audit work.

85. 1 AlCPA PROFESSIONAL STANDARDS (CCH) AU \& 338.02.

86. Hanson \& Brown, supra note 13, at 74. The first standard of audit field work requires that "assistants, if any, are to be properly supervised." 1 AICPA Professional STANDARDS $(\mathrm{CCH}) \mathrm{AU} \$ 150.02$. This supervisory review is necessary as field work is often performcd by accountants with limited audit experience. More experienced CPAs then review the workpaper documentation of work performed. 
dition, forcing professional accountants to disguise their work is as untenable as forcing attorneys to leave their legal arguments unwritten. The Hickman work-product rule protects attorneys from that threat; 87 similar protection for CPAs is reasonable.

\section{Possible Judicial Responses.}

A solution to the problem could come from the courts, but they would have to abandon soine established precedents. In view of the IRS's tacit acceptance of the CPAs' arguments, and the mcreasing tensions generated by this conflict, the courts should make such a reassessinent.

The Court in United States v. Powell ${ }^{88}$ established the basic test the courts use to review the propriety of an IRS summons. According to Powell, the IRS "must show that the imvestigation will be conducted pursuant to a legitimate purpose, that the inquiry may be relevant to the purpose, that the information sought is not already within the Commissioner's possession, and that the administrative steps required by the Code have been followed." 89 The IRS usually has hittle problem showing a legitmate purpose for an investigation, given the courts' liberal views of the IRS's investigatory powers. 90 Compliance with administrative steps is seldom difficult because Powell requires only procedural compliance with the tax code..$^{91}$ Thus, litigation usually focuses on two issues: whether the information is relevant and whether the information is already in the Commissioner's possession.

Most litigation has concerned the relevancy of the auditor's workpapers.92 These workpapers generally are not sources for tax return preparation. ${ }^{93}$ They contain either basic information supplied by

\footnotetext{
87. See text accompanying note 50 supra.

88. 379 U.S. 48 (1964).

89. Id. at 57-58. The courts have applied this test in numerous cases. See, e.g., United States v. Coopers \& Lybrand, 550 F.2d 615, 619-20 (10th Cir. 1977); United States v. Arthur Andersen \& Co., 474 F. Supp. 322, 327-28 (D. Mass. 1979), appeal dismissed as moot, 623 F.2d 720 (Ist Cir.), cert. denied, 449 U.S. 1021 (1980).

90. See note 8 supra and accompanying text.

91. United States v. Powell, 379 U.S. at 57-58. See United States v. Price Waterhouse \& Co., 515 F. Supp. 996, 999 (N.D. Ill. 1981).

92. United States v. Arthur Young \& Co., 82-1 U.S.T.C. 9320 (2d Cir. 1982); United States v. Coopers \& Lybrand, 550 F.2d 615 (10th Cir. 1977); United States v. Price Waterhouse \& Co., 515 F. Supp. 996, 999-1000 (N.D. Ill. 1981); United States v. Arthur Andersen \& Co., 474 F. Supp. 322, 327-30 (D. Mass. 1979), appeal dismissed as moot, 623 F.2d 720 (1st Cir.), cert. denied, 449 U.S. 1021 (1980).

93. See United States v. Coopers \& Lybrand, 550 F.2d 615, 618 (10th Cir. 1977). Audit workpapers usually are not used in tax return preparation. Auditors do not perform tax return services as part of an audit, and in a large CPA firm, the audit and tax departments are generally separate. The CPA firm in Coopers \& Lybrand had no return preparation responsibilities. Id. In
} 
the company or the CPA's analysis of that information. The workpapers often contain conjectures. Thus the CPAs argue that such speculative papers are irrelevant to the IRS's investigation of the coinpany's actual tax return. ${ }^{94}$

Several courts have disagreed with the CPAs. ${ }^{95}$ Their analysis has been guided by the hiberal construction required by the wording of section $7602,{ }^{96}$ which permits access to information that "may be relevant" to determining the correctness of a tax return. ${ }^{97}$ All the IRS must show is that the desired records might throw light upon the correctness of a taxpayer's return..$^{98}$ Admittedly, the auditor's workpapers do shed some hight on the taxpayer's tax positions, but their focus is on the potential effect of these positions on the financial statements rather than on the correctness of the tax return. ${ }^{99}$ Auditor's workpapers thus reflect only indirectly on the tax position and should be regarded as little more than a convemence to the IRS.

The courts generally do not allow convenience alone to justify IRS access to records. ${ }^{100}$ For example, in United States $v$. Matras, ${ }^{101}$ the court refused to enforce an IRS summons requesting budgets prepared by the company. The court held that these budgets were not relevant to the tax return because they reflected only the company's plans for the year under review, not the actual figures used in computing the tax

contrast, in the Arthur Andersen case, the CPA firm did perform return preparation services. See 474 F. Supp. at 323-24.

As a practical inatter, an auditing firm that also prepares the audited company's tax returns nnay use the audit workpapers to assist with the tax return. If so, the specific workpapers used should be accessible to the IRS. Tax investigations would be impossible if taxpayers and their tax preparers could deny the IRS access to tax preparation inaterials.

94. See cases cited in note 92 supra. 1982).

95. See note 12 supra. See also, United States v. El Paso Co., 82-2 U.S.T.C. I 9534 (5th Cir.

96. See notes 7-10 supra and accompanying text. The Court of Appeals for the Second Circuit applied this liberal construction to permit access to the auditors' workpapers in general. United States v. Arthur Young \& Co., 82-1 U.S.T.C. I 9320 (2d Cir. 1982). Similarly, the court noted that the tax accrual workpapers were relevant, but denied access on public policy grounds. Id.

97. See note 7 supra.

98. Umited States v. Shlom, 420 F.2d 263, 265 (2d Cir. 1969), cert. denied, 397 U.S. 1074 (1970); Venn v. United States, 400 F.2d 207, 212 (5th Cir. 1968); United States v. Harrington, 388 F.2d 520, 523-24 (2d Cir. 1968); Foster v. United States, 265 F.2d 183, 187 (2d Cir.), cert. denled, 360 U.S. 912 (1959).

99. See text accompanying notes $29-30$ supra. Fimancial statements are correct if they comply with Generally Accepted Acconnting Principles. Tax returns must comply with the tax code. GAAP and tax requirements are often quite different.

100. See, e.g., United States v. Coopers \& Lybrand, 550 F.2d 615, 620-21 (10th Cir. 1977); U1nited States v. Matras, 487 F.2d 1271, 1275 (8th Cir. 1973). But see United States v. Amerada Hess Corp., 619 F.2d 980, 988 (3d Cir. 1980).

101. 487 F.2d 1271 (8th Cir. 1973). 
hability. ${ }^{102}$ The tax contimgency inemorandum also contains speculations rather than actual results. In United States v. Arthur Young \& Co., the district court held the audit work programs to be irrelevant because they were too "many steps removed from the question of the actual tax liability." 103 And in United States $v$. Coopers \& Lybrand the court held that the IRS had not shown that either the auditor's work programs or the tax accrual workpapers were relevant. ${ }^{104}$ Thus, the courts have used irrelevancy to limit access to some of the workpapers.

Litigation has also focused on whether the information is already in the IRS's possession. ${ }^{105}$ The courts have held that the IRS has the right not only to the company's factual information, but also to the CPA's opinion based on this information. ${ }^{106}$ The CPA's opinion is in the audit workpapers. Although without these workpapers the IRS does not have the full opinion of the CPA, the IRS probably could obtain every material fact in the CPA's workpapers froin the taxpayer company without actually obtaining the workpapers. For example, the most important information, the tax return preparation materials, should be either in the company's possession or obtainable froin the company's auditor. ${ }^{107}$

In addition, compamies also possess inuch information discovered by CPAs durimg their audits. Although auditors are generally not required to publicly "blow the whistle" on companies, an auditor who finds material problems in the tax analysis will notify the company of them. ${ }^{108}$ This notification to the company may take several forms, any of which the IRS should be able to obtain from the taxpayer. ${ }^{109}$ Material accounting errors, including understated tax liabilities, require audit adjustments. ${ }^{10}$ Companies must have these adjustments to reconcile their general ledgers with their financial statements, so the

102. Id. at 1273-75.

103. 496 F. Supp. 1152, 1157 (S.D.N.Y. 1980), rev'd in part, 82-1 U.S.T.C. I 9320 (2d Cir. 1982).

104. 550 F.2d 615, 619-21 (10th Cir. 1977).

105. See notes 88-89 supra and accompanying text.

106. CPA arguments alleging possession have been rejected by "every court that has considered the question" because "the IRS has the right to review documents containing opinions, regardless of whether the government already has documents that contain the factual basis for those opinions." Umited States v. Price Waterhouse \& Co., 515 F. Supp. 996, 999 (N.D. Ill. 1981).

107. See, eg., Couch v. United States, 409 U.S. 322 (1973).

108. See Chazen, Miller \& Soloinon, When the Rules Say: "See Your Lawyer", J. AccT. 60, 66-70 (Jan. 1981). After the auditor notifies the company, the IRS should have access to information on which the notification is based unless such information is protected by a privilege. See notes 69-71 supra and accoinpanying text.

109. See note 71 supra and text accompanying notes 114-19 infra concerning IRS access to taxpayer information generally.

110. Cook \& Winkle, Auditing Philosophy ANd Technique 198-99 (1976). 
IRS should be able to obtain these from the company. If a necessary audit adjustment is not unade to the financial statements, then the audit opinion will be qualified. ${ }^{111}$ The IRS can gain access to company financial statements. IRS procedures require the agent to determine why opinions are qualified; $;^{112}$ companies inust supply this information. If the CPA finds internal control deficiencies he must report thein to the company, ${ }^{113}$ and the IRS can obtain this report from the coinpany. ${ }^{114}$ Furthermore, "inaterial errors or irregularities" discovered by the auditor must be reported to the company's board of directors. ${ }^{115}$ The directors of the company should discuss these errors at the board of directors meeting, and the IRS can gain access to the inimutes of the meeting from the company. ${ }^{116}$ Auditors encountering material irregularities may withdraw from the audit ${ }^{117}$ and the IRS can easily discover, often from company filings with the SEC, that the company has changed auditors. ${ }^{118}$ The IRS can ask the company the reason for the change. Thus, the IRS can discover the gist of the CPAs' assessment of the tax accounts without reviewing the workpapers. The goal of access to material, ${ }^{119}$ tax-related information can be fulfilled, therefore, without the problems inherent in full access to the auditors' workpapers.

The preceeding discussion shows that a reassessment of the Powell tests of relevancy and IRS possession could help resolve the conflict over access to CPA workpapers. This approach, however, would inean overturning established precedents, which is unlikely. Overturning these precedents, even if all courts were willing to do so, would take time. During this waiting period commumications between CPAs and compamies will contimue to deteriorate. Any change that comes may

111. 1 AICPa Professional Standards (CCH) AU § 328.15.

112. Internal ReVEnUe MANUAL, supra note $4, \S 4026$.

113. 1 AICPA Professional Standards (CCH) AU \& 323.01. Internal controls are the company's checks in its accounting system designed to ensure proper accounting for financial transactions. CPAs, as part of their audit, review the company's accounting system and its internal controls. Id.

114. United States v. Riley, 45 A.F.T.R. 2d 80-1164 (N.D. Ill. 1980) (mem.) appeal dismissed, No. 80-1124 (7th Cir. Sept. 16, 1980).

115. 1 AICPA Professional Standards (CCH) AU § 327.14.

116. Umited States v. Acker, 325 F. Supp. 857 (S.D.N.Y. 1971).

117. I INTERNAL REVENUE MANUAL, supra note 4, \$ 4026.

118. Chazen, supra note 108 , at $69-70$. SEC form $8-\mathrm{K}$ requires companies to disclose changes in auditors and the reasons for these changes. $I d$.

119. These alternate methods may not give the IRS access to items noted by the auditor that are immaterial from a GAAP standpoimt. A basic feature of financial accounting is its stress on materiality. "[F]imancial reporting is only concerned with significant information." 3 AICPA PROFESSIONAL STANDARDS (CCH) AC $\S 1022.17$. Thus the auditor's work and his results are directed at material items with materiality measured in relation to the financial statements taken as a whole. Presumably, an IRS agent focuses more on materiality with respect to the tax return. Any illegality noted by the CPA is material. Id. 
arrive too late. Thus, although review by the Supreme Court would resolve the conflict in a timely inanner, waiting for the lower courts to reassess the Powell tests is not a viable solution to this immediate problem.

Another possible solution to the problem is for courts to perform in camera review of workpapers to determine if the workpapers are relevant. Without this review, the courts tend to be liberal in defining relevancy because they are unable to fully understand the workpapers. ${ }^{120}$ Despite this risk of overbroad interpretation of the relevancy test, the courts have generally refused to perform in camera imspections because they consider them to be so "burdensone" and "impossible of performance" that Congress could not have intended busy district court judges to perform thein in CPA workpaper cases. ${ }^{121}$

This recalcitrant attitude toward in camera inspections is unrealistic because the papers actually in dispute are fairly limited in number and in length. Audit workpapers may be voluminous as a wliole, but the real dispute does not concern all of the CPAs' workpapers. The dispute concerns the audit work programs and the tax accrual contimgency memoranda. ${ }^{122}$ Work prograins generally are not overly long and are repetitive, so judicial review would not be difficult. ${ }^{123}$ More importantly, the tax accrual inemorandum, the inost critical iten, is generally no longer than a few pages; certainly even a busy district court judge could review it, given the serious issues involved.

Courts could also reinedy the problem of access to CPA workpapers by establishing an accountant-chent privilege. ${ }^{124}$ At present no such privilege exists under federal law, ${ }^{125}$ although sixteen states

120. Hanson \& Brown, supra note 13 , at 74 .

121. United States v. Noall, 587 F.2d 123, 127 (2d Cir. 1978) (referring to internal audit workpapers); see United States v. Arthur Young \& Co., 496 F. Supp. 1152, 1156 (S.D.N.Y. 1980), rev'd in part, 82-1 U.S.T.C. I 9320 (2d Cir. 1982). The government objected to in camera review in the Coopers \& Lybrand case. Barnes, supra note 18, at 45 . The IRS opposes in camera review because of its desire to protect its "prerogative to conduct independent audits and decide for itself what is relevant." Nath, supra note 6 , at 1615.

122. See notes 4-5 supra and accompanying text.

123. This assumes, of course, that the court needs to review them; two cases have held that these programs are not relevant. See text accoinpanying notes 103-04 supra.

124. See Hanson \& Brown, supra, note 13 at 76. The Court of Appeals for the Second Circuit adopted a limited accountant work product "privilege" to protect parts of the audit workpapers in United States v. Arthur Young \& Co., 82-1 U.S.T.C. If 9320 (2d Cir. 1982).

125. Couch v. United States, 409 U.S. 322, 335 (1973); Urited States v. Price Waterhouse \& Co., 515 F. Supp. 996, 998 (N.D. Ill. 1981); United States v. Arthur Andersen \& Co., 474 F. Supp. 322, 326-27 (D. Mass. 1979), appeal dismissed as moot, 623 F.2d 720 (1st Cir.), cert. denied, 449 U.S. 1021 (1980); 13 AM. JUR. TRIALS $\$ 37$ (1967). The Fifth Circuit recently held that because no accountant-client privilege exists, showing workpapers to the company's independent CPA auditors violates the attorney-chent privilege. See United States v. El Paso Co., 82-1 U.S.T.C. I 9534 
do recognize such a privilege. ${ }^{26}$ These state laws are not binding, however, in federal administrative proceedings. ${ }^{127}$

Establishment of a federal accountant-client privilege would probably require congressional action; however, the Federal Rules of Evidence might allow the courts to establish such a privilege. The rules impose on the courts "a special duty to clarify aspects of the law of privileges." 128 Federal Rule of Evidence 501 states that privileges are "governed by the principles of the common law as they inay be interpreted by the courts of the United States in the light of reason and experience." 129 This flexible rule evinces a congressional intent "not to freeze the law of privileges." 130 No accountant-client privilege existed at common law ${ }^{131}$ because accounting has only recently achieved professional status. Today, stringent professional regulations, similar to those governing the legal profession, ${ }^{132}$ govern the accounting profession. Work perforned by CPAs, particularly in the tax fleld, often resembles that of lawyers. ${ }^{133}$ For example, CPAs prepare tax returns and advise chents on requirements of the tax code just as lawyers do. Because lawyers are bound by an attorney-client privilege, recognition of an accountant-client privilege could be viewed as an interpretation of the common law in light of nodern reason and experience.

Communications to the modern CPA do meet the requirenients asserted by Wigmore for privilege:

1. The communications must originate in a confidence that they will not be disclosed.

2. This element of confidentiality must be essential to the full and satisfactory mamtenance of the relation between the parties.

(5th Cir. 1982). Privileges are generally waived by showing documents to outside parties; however, the Fifth Circuit's approach increases the penalty for candid discussion with the coinpany's CPA. But see United States v. Arthur Young \& Co., 82-1 U.S.T.C. 9320 (2nd Cir. 1982) (adopting an auditors' work product "privilege").

126. Hanson \& Brown, supra note 13, at 72; Jentz, Accountant Privileged Communications: Is it a Dying Concept Under the New Federal Rules of Evidence?, 11 AM. Bus. L.J. 149, 152 (1973).

127. Falsone v. United States, 205 F.2d 734, $741-42$ (5th Cir.), cert. denied, 346 U.S. 864 (1953); Jentz, supra note 126 at 149-50.

128. Upjohn Co. v. United States, 449 U.S. 383, 403 (1981) (Burger, C. J., concurring).

129. FED. R. Evid. 501.

130. Trammel v. United States, 445 U.S. 40, 47 (1980).

131. Falsone v. United States, 205 F.2d 734, 739 (5th Cir.), cert. denied, 346 U.S. 864 (1953).

132. See Katsoris, Confidential Communications-The Accountants' Dilemma, 35 FordHAM L. Rev. 51 (1966). Accountants govern themselves with regulations. See, e.g., 1-4 AICPA ProfesSIONAL STANDARDS (CCH). These regulations are similar to the American Bar Association rules governing lawyers. In addition, the states regulate the public practice of CPAs. These requirements generally include a national CPA examination and a one to five year experience requirement. See generally ACCOUNTANCY L. REP. (CCH) (compilation of state accountancy rules).

133. Jentz, supra note 126 , at 151 . 
3. The relation inust be one which in the opinion of the community ought to be sedulously fostered.

4. The injury that would inure to the relation by the disclosure of the communications inust be greater than the benefit thereby gained for the correct disposal of hitigation. ${ }^{134}$

Companies expect that communications with their auditors will be kept confidential. This confidentiality must be preserved if companies are to confide in their auditors. Confidentiality is important because the business community considers full disclosure to CPAs necessary to protect the public from economic injury. ${ }^{135}$

Estabhshing a full accountant-chent privilege would resolve the audit workpaper conflict, but creating this privilege raises certain objections such that many commentators do not believe that CPAs should have this privilege. ${ }^{136}$ First, any such privilege would have to be limited because CPAs sometimes need to disclose the contents of their workpapers. For example, a CPA inay need to use the workpapers to defend a suit for negligently conducting an audit. A privilege of the CPA's client could greatly limit the CPA's ability to do this. ${ }^{137}$ Second, the pohcy in this country is to limit privileges, not to extend them. As the Supreme Court stated in United States $v$. Nixon: ${ }^{138}$ "[t] $]$ he public .. . has a right to every man's evidence." 139 Thus, creating a full accountant-chent privilege is not necessarily an acceptable solution to the IRS-CPA workpaper conflict. The courts could, though, create a limited privilege such as the attorney work-product rule created by the Supreme Court in Hickman v. Taylor ${ }^{140}$ and now enibodied in Federal Rule of Civil Procedure 26.141 The Court of Appeals for the Second Circuit adopted this approach in United States v. Arthur Young \& Co.,

134. WIGMORE, EVIDENCE $\$ 2285$ (McNaughton rev. ed. 1961) (einphasis in original). Wigmore also recognized a privilege concerning information given to persons who appear before administrative tribunals representing parties in interest "as a hicensed body having the responsibilities of attorneys and subject to professional discipline." Id. \$2300(a). See also Falsone v. United States, 205 F.2d 734, 740 (5th Cir.), cert. denied, 346 U.S. 864 (1953). CPAs are a licensed body with professional discipline and responsibility similar to that of attorneys. See note 132 supra.

135. See note 14 supra and accompanying text.

136. See Jentz, supra note 126, at 156-59 (list of arguinents both for and against accountantclient privilege); Note, Evidence-Privileged Communications-Accountant and Client, 46 N.C.L. Rev. 419 (1968) (opposing privilege). But see Note, Privileged Communications-Accountants and Accounting-A Critical Analysis of Accountant-Client Privilege Statutes, 66 Mich. L. REv. 1264 (1968) (supporting privilege).

137. Jentz, supra note 126 , at 157.

138. 418 U.S. 683 (1974).

139. Id. at 709 (quoting United States v. Bryan, 339 U.S. 323, 331 (1950)).

140. 329 U.S. 495 (1947). See text accompanying notes $45-50$ supra.

141. See text accompanying notes $146-47$ infra. 
the inost recent CPA workpaper case. ${ }^{142}$ Since the courts liave split over the adoption of such a rule, however, this comment advocates that Congress take action to resolve the problem.

\section{Possible Congressional Solution.}

Congress could resolve the conflict between the CPAs and the IRS by annending section 7602 of the Code to limit access to certain thirdparty records. ${ }^{143}$ The IRS opposes such a change, claiming that the IRS "would lose all flexibility to see workpapers," 144 but a congressional change need not be that restrictive. The workpapers actually in dispute, the tax contingency memoranda and the audit work programs, ${ }^{145}$ are limited in number and content so only a limited change would be necessary to resolve this problem. The protection sliould be broad enough, however, to include workpapers with information comparable to that in the tax contingency memorandum, which is located elsewhere in the auditors' workpapers.

As the Arthur Young court and one commentator have concluded, a rule similar to Federal Rule of Civil Procedure 26, concerning the attorney's work product, would be a feasible solution. ${ }^{146}$ Rule 26 permits discovery of an attorney's work product "only upon a showing that the party seeking discovery has substantial need of the materials ... and that he is unable witlout undue hardship to obtain the substantial equivalent." Rule 26 further provides that "tlie court shall protect agamst disclosure of the inental impressions, conclusions, opinions,

142. 82-1 U.S.T.C. I 9320 (2d Cir. 1982). The rule adopted in Arthur Young seems to have two possible limitations. First, it appears limited to companies governed directly by the securities laws. It is anomolous, though, to give the work-product privilege to the most highly regulated companies while denying it to other, generally smaller, companies that are less exposed to public scrutiny.

Second, the Arthur Young court seems to say the privilege would cease to exist in a fraud investigation. Id. at 83828 . This is reasonable, but it ignores the duty of the CPA to indirectly "blow the whistle" on fraud. See notes 108-09 supra and accompanying text. Thus if the workpapers reveal fraud, other more accessible means should also reveal fraud.

143. See Sumner \& Reed, supra note 12 at 75. See also Reports of Committees, 34 TAX LAw. 897,897 (1981) (An ABA subcommittee is presently working on a legislative proposal to give a qualified privilege to accountants' workpapers). See generally Diss \& Hanson, supra note 41 at 114; Hanson \& Brown, supra note 13 at 76; Note, Government Access to Corporate Documents and Auditors' Workpapers: Shall we Include Auditors Among the Privileged few? J. CoRP. LAw 367, 387-88 (1977).

In United States v. Arthur Young \& Co. Judge Newman argued that Congress should be the body to adopt the accountants' workpaper privilege advocated by the majority. See 82-1 U.S.T.C. 9320 (2d Cir. 1982) (concurring in part and dissenting in part).

144. Tax Feature, J. OF ACCT. 51, 51 (Sept. 1981).

145. See notes 4-5 supra and accoinpanying text.

146. See 82-1 U.S.T.C. If 9320; Note, supra note 12 at 206-09. 
or legal theories of an attorney."147 A similar rule for the auditor's work product would permit IRS access to the audit workpapers if they are the only reasonable source of information, thereby allowing the IRS to fulfill its investigatory responsibilities. At the same time, the proposed rule would bar any access to mental impressions, which would include the tax contingency memoranda and, arguably, the audit work programs. ${ }^{148}$ This limitation should satisfy the CPAs.

Limiting IRS access by means of a CPA work-product rule finds support $\mathrm{m}$ analogous limitations imposed on the IRS by the attorney work-product rule and the attorney-client privilege. The Supreme Court recently held in Upjohn Co. v. United States ${ }^{149}$ that the attorney work-product rule applies to IRS summons proceedings. The Court recognized the "strong public policy" implications of this rule. 150 As discussed earlier, many of these pubhic pohicy concerns are analogous to the policy imphications of a CPA work-product rule for auditors. ${ }^{151}$ In addition, the Upjohn Court extended the attorney-chent privilege to company personnel outside of the company's controI group, thus adopting the broadest privilege recognized for corporate einployees assisting an attorney. ${ }^{152}$ The Court did so despite its general policy favoring liberal discovery, ${ }^{153}$ and despite the broad investigatory powers of the IRS. ${ }^{154}$ The Court considered the policy imphications of the attorney-client privilege paramount: "Its purpose is to encourage full and frank communication between attorneys and their clients and thereby promote broader public interests."15s Full and frank communications to CPAs also promote public interests. ${ }^{156}$ That the Upjohn Court was willing to balance important policy considerations in ex-

147. FED. R. CIV. P. 26(b)(3). Admittedly, this rule relates to materials "prepared in anticipation of litigation." Id. This requirement arises froun the nature of an attorney's work and should not affect the remaining analysis of the need for a work-product rule for CPAs.

148. The audit work programs are the CPA's mental impression of the proper steps to be completed in auditimg a company's financial statements. This application of the mental-impressions test to audit work programs is somewhat tenuous, but the reasons for protection of the audit work programs are equally tenuous. See text accompanying notes 64-6 supra. Also, the work programs may be protected by the Powell relevancy test and, hence, may be less vulnerable. See text accompanying notes 103-04 supra. The proposed test would provide courts with the leeway to protect the audit work programs in the appropriate case, but would permit IRS access to the work programs if the policy reasons for access override those reasons against it.

149. 449 U.S. 383 (1981).

150. Id. at $397-402$.

151. See notes $45-50,59-61$ supra and accompanying text.

152. 449 U.S. at $390-97$.

153. See note 46 supra and accompanying text.

154. See note 15 supra and accompanying text.

155. 449 U.S. at 389.

156. See text accompanying note 14 supra. 
tending the attorney-client privilege to IRS proceedings suggests that extending a similar, limited protection for CPAs is reasonable, given the important policy considerations for protecting CPAs' workpapers. It was this balancing approach that the Court of Appeals for the Second Circuit used to create, in effect, an accountant work-product privilege in United States v. Arthur Young \& Co. ${ }^{157}$

\section{ConClusion}

The conflict between the CPAs and the IRS over auditors' workpapers has already begun to limit the CPAs' ability to perform an audit sufficient to meet the needs of the imvesting public. ${ }^{158}$ Recognizing this, the IRS lias clianged its procedures to limit its interference witl CPA audits. The effectiveness of these changes depends on IRS self-control, however. ${ }^{159}$ CPAs are unwilling to depend on this IRS self-control and have suggested changes in the audit process that ultimately will reduce the effectiveness of the audit. ${ }^{160}$ Thus, more protection for the auditor's workpapers is needed. The courts could provide this protection by reassessing the precedents in this area of the law, but judicial change miglit come too slowly to provide the immediate protection auditors need. ${ }^{161}$ Therefore, Congress slould amend section 7602 of the Code to limit access to certain third party documents. ${ }^{162}$

In determining which documents sloould be protected, Congress must consider the needs of both the IRS and the CPAs. The IRS must not be unduly limited in its ability to investigate, so the limitations im the new law must be specific. Only the tax contimgency memorandum and the audit work programs, botlı of which contam the CPAs' inental impressions concerning the company's tax positions and audit procedures, need protection. ${ }^{163}$ Thus, a rule similar to the attorney workproduct rule, whicle permits access to workpapers when necessary to avoid hardship but permits no access to mental impressions, should satisfy both the CPAs and the IRS.

Jean Gordon Carter

157. 82-1 U.S.T.C. \ 9320 (2d Cir. 1982); see also Note, supra note 12 at 206-09.

158. See note 36 supra and accompanying text.

159. See text accompanying notes 72-81 supra.

160. See text accompanying notes 83-87 supra.

161. See text preceding note 120 supra.

162. See note 143 supra and accompanying text.

163. See notes $145-48$ supra and accompanying text. 